\title{
Genetic and Molecular Aspects of Thyrotoxic Cardiomyopathy
}

\author{
Darya Aleksandrovna Savitskaya ${ }^{1 *}$ and Babenko AYu ${ }^{2}$ \\ ${ }^{1}$ Federal North-West Medical Research Centre, Russia \\ ${ }^{2}$ Almazov National Medical Research Centre, Russia
}

Submission: December 10, 2017; Published: February 26, 2018

*Corresponding author: Darya Aleksandrovna Savitskaya, Federal North-West Medical Research Centre, Russian Federation, Russia, Email: Savitskayadaria@gmail.com

\section{Introduction}

In this review we focused on the cardiomyopathy, which develops secondary to thyrotoxicosis. Whereas its secondary etiology, there is still evidence of heritable component. The investigation of molecular and genetic basis of thyrotoxic cardiomyopathy (TCMP) can improve treatment strategies and provide new potential drug targets for its therapy. Also increasing understanding of the pathophysiology of TCMP will improve risk prediction of severe cardiovascular complication in patients with thyrotoxicosis. One of the genetic basis research directions is study of the single nucleotide polymorphisms (SNPs) of various genes, so-called genes of susceptibility or genes - candidates. It is significant line of TCMP investigation because limited success in severe TCMP treatment is due to the less understanding of its molecular pathophysiology.

Recent studies have shown the associations of different TCMP components with SNPs in genes encoding proteins involved in thyroid hormones effects on tissues and arrhythmogenesis. Thyroid hormone effects on the heart are multiple and are largely mediated by triiodothyronine (T3) acting through nuclear-based thyroid receptors [1]. Type 2 deiodinase (D2) is assumed to play the key role in $\mathrm{T} 3$ tissue concentration changes, at least, in the tissues (such as myocardium, vessel wall) with high D2 gene expression. To date, there are a lot of data about association of SNPs in D2 gene with changes in D2 activity. One of them is Thr92Ala. Ala/Ala homozygous patients demonstrate lower D2 tissue activity compared to Ala/Thr heterozygous and Thr/ Thr homozygous patients. Therefore, this polymorphism can decrease T3 effects in tissues with high D2 gene expression [2,3]. In 2009, Grineva et al. [4] reported that SNP Thr92Ala in type D2 contributes to the severity of TCMP. According to this research of 145 patients with Graves' disease Thr92Ala D2 polymorphism is associated with lower heart rate, left ventricular mass index (LVMI) and lower risk of concentric left ventricle hypertrophy (LVH) [4]. Heart rate in Thr/Thr homozygous and heterozygous patients ( $99.8 \pm 3.01$ and $96.7 \pm 2.80$ beats/min, correspondingly) was significantly higher than in Ala/Ala homozygous ones
(87.2 \pm 5.30 beats/min, $\mathrm{p}<0.01)$. Thr/Thr allele prevalence in patients LVH was almost twice as high as in patients without LVH (75\% compared to $49.5 \%, \mathrm{p}=0.01$ ). So, Ala/Ala homozygous patients have less severe TCMP.

Another gene, involved in thyroid hormones impact on the myocardium is KCNE1gene, which encodes the minK peptide, associates with KCNQ1 in vitro to generate a potassium current closely resembling the slowly activating delayed rectifier (IKs) [5]. The findings indicate that KCNE1 gene is $\alpha$-thyroid receptors targets and is regulated by thyroid status: a marked decrease in min K mRNA occurs in hyperthyroid mice' hearts and hearts of T3$\beta$-receptor knockout mice [6]. Moreover, literature data show the strong association of the polymorphism Ser38Gly in KCNE1 gene and some cardiac diseases such as long QT syndrome and atrial fibrillation [7]. All these finding make KCNE1 gene and its SNP Ser38Gly interesting to investigate in patients with TCMP. Data from the study of 165 patients with Graves' disease have shown an interaction of this SNP with TCMP in patients aged 45 and older. In this age group atrial fibrillation (AF) was significantly more prevalent in GG genotype carriers: $35.3 \%$ (GG) vs $13.9 \%$ $(A G+A A)(p=0.037)$. Also, there was a significant difference in systolic blood pressure (SBP) by KCNE1 codon 38 genotypes. SBP were significantly higher in allele $\mathrm{G}$ homozygotes as compared to allele A carriers: $124.89 \pm 15.14 \mathrm{~mm} \mathrm{Hg}$ vs $131.35 \pm 15.32 \mathrm{~mm} \mathrm{Hg}$ $(\mathrm{p}=0.012)[8]$.

Recently it was considered that $\beta 1$-adrenergic receptor (ADRB1) gene is also candidate gene for TCMP prediction, because of it mediates the sympathetic inotropic and chronotropic effects in the heart and is involved in arrhythmogenesis [9-11], because the density of $\beta 1$-AR in myocardium during thyrotoxicosis is considerably increased and thyroid hormones are important elements of the regulation of $\beta 1-\mathrm{AR}$ expression and $[12,13]$. But several recent studies in TCMP genetics have concluded that frequent polymorphisms in $\beta 1$-adrenoreceptor gene ( $\beta$ 1-AR) Gly389Arg and Ser49Gly have no strong associations with myocardial remodeling (evaluated by echocardiography 
parameters)and arrhythmias in patients with thyrotoxic determined heart damage. Only the tendency to more prominent LVH was noted when we compare A allele carriers with GG genotype in SNP Ser49Gly: LVMI was $99.1 \pm 23.8 \mathrm{~g} / \mathrm{m}^{2}$ among $\mathrm{AA}+\mathrm{AG}$ carriers and $118.9 \pm 44.9 \mathrm{~g} / \mathrm{m}^{2}$ among patients with $\mathrm{GG}$ genotype $(p=0.02)$ [14].

In $2005 \mathrm{Kim}$ M showed that the decrease in the production of nitride oxide synthase (NOS) can cause oxidative stress and lead to changes in myocardial conduction system, thereby contributing to the development of AF [15]. The investigation of polymorphism $4 \mathrm{a} 4 \mathrm{~b}$ in endothelial nitride oxide synthase (eNOS) gene, decreasing NOS activity, hasn't demonstrated any interactions between genotypes of this SNP and severity of TCMP among patients with Graves' disease [16].

Not only can the identification of SNPs, associated with heart damage in thyrotoxicosis, provide new predictors of TCMP detection. Other genetic research methods were used in the study by De et al. [17]. Analysis of differentially expressed genes in hyperthyroid-induced hypertrophied heart by cDNA microarray. Using complementary DNA microarray comprising 588 genes, the differences in micro RNA expression of hyperthyroid and normal rat heart we compared. About 37 genes were found to be regulated by $\mathrm{T} 3$, encoding various types of proteins related to metabolism, matrix and cytoskeletal structures, growth factors, transcription factors, Ca2+-channels. Alteration of insulinresponsive glucose transporter type 4 (GLUT4) expression was shown to be one of the obvious features of hyperthyroid-induced altered gene expression. Inhibition of GLUT4 expression by thyroid hormones leads to impaired glucose transport into the myocytes [17]. So, this is another potential pathophysiological mechanism of TCMP development. And future investigations in this area can clarify, whether micro RNA expression of GLUT4 associates with the severity of TCMP or not.

To date, along with genetic predictors, a lot of new molecular markers of severe TCMP were determined. In 2012, Ozaydin et al. [18] have shown recent that inflammation is involved in the thyrotoxic AF. This study suggests that $\mathrm{C}$ reactive protein is associated with the development of $\mathrm{AF}$ in patients with thyrotoxicosis. Another study by Galloway et al has revealed that b1-adrenergic receptor (b1AR) and M2 muscarinic receptor (M2R) autoantibodies are independent predictors of $\mathrm{AF}$ in patients with hyperthyroidism. In this case AF provoking is performed by inducing rapid depolarization in pulmonary veins [19].

Also, series of recently conducted studies are focused on the role of oxidative stress in TCMP development. They have shown (on the hearts of experimental animals with thyroid hormoneinduced cardiac hypertrophy) that oxidative stress is either not or only partially involved in the thyroid hormones induced cardiomyocyte hypertrophy, but it seems to be a key player in the thyrotoxic left ventricular dysfunction [20].

\section{Conclusion}

The new insights on gene, genotype correlations and molecular mechanisms involved in thyrotoxic cardiomyopathy development may impressively increase our understanding of the pathophysiological mechanisms leading to myocardial damage in thyrotoxicosis. The new knowledge supports investigations about novel disease genes associations, their interactions with remodeling mechanisms, and potential therapies to treat thyrotoxic cardiomyopathy at the ion channel and cellular levels. Eventually genomic information in thyrotoxic patients will impact the optimal approach to care, from prevention and diagnosis to therapy and counseling.

\section{References}

1. Grais IM, Sowers JR (2014) Thyroid and the heart. Am J Med 127(8): 691-698.

2. Bianco AC, Salvatore D, Gereben B, Berry MJ, Larsen PR (2002) Biochemistry, cellular and molecular biology, and physiological roles of the iodothyronine selenodeiodinases. Endocr Rev 23(1): 38-89.

3. Köhrle J (1999) The trace element selenium and the thyroid gland. 81(5): 527-533.

4. Grineva E, Babenko A, Vahrameeva N, Bogdanova M, Kostareva A, et al. (2009) Type 2 deiodinase Thr92Ala polymorphism impact on clinical course and myocardial remodeling in patients with Graves' disease. Cell Cycle 8(16): 2565-2569.

5. Lundquist AL, Manderfield LJ, Vanoye CG, Rogers CS, Donahue BS, et al. (2005) Expression of multiple KCNE genes in human heart may enable variable modulation of IKs. J Mol Cell Cardiol 38(2): 277-287.

6. Gloss B, Trost S, Bluhm W, Swanson E, Clark R, et al. (2001) Cardiac Ion Channel Expression and Contractile Function in Mice with Deletion of Thyroid Hormone Receptor $\alpha$ or $\beta 1$. Endocrinology 142(2): 544-550.

7. Liang C, Li X, Xu Y, Chen Q, Wu Y, et al. (2013) KCNE1 rs1805127 Polymorphism Increases the Risk of Atrial Fibrillation: A Meta-Analysis of 10 Studies. PloS one 8(7): e68690.

8. Savitskaya DA, Babenko AY, Kostareva AA, Grineva EN (2015) SNP Ser38Gly in the $\beta$-subunit of potassium channel gene KCNE1 and thyrotoxic cardiomyopathy in patients with Graves' disease. Klinicheskaya I eksperimental'naya tireoyydilogiya 11(3): 24-33.

9. Strader CD, Fong TM, Tota MR, Underwood D, Dixon RAF (1994) Structure and function of G protein-coupled receptors. Annu Rev Biochem 63: 101-132.

10. Brodde OE, Bruck H, Leineweber K, Seyfarth T (2001) Presence, distribution and physiological function of adrenergic and muscarinic receptor subtypes in the human heart. Basic Res Cardiol 96(6): 528538.

11. Yatani A, Brown AM (1989) Rapid $\beta$-adrenergic modulation of cardiac calcium channel currents by a fast $G$ protein pathway. Science 245(4913): 71-74.

12. Williams LT, Lefkowitz RJ (1997) Thyroidhormone regulation of $\beta$ adrenergic receptor number. J Biol Chem 252(8): 2787-2789.

13. Bahouth SW (1991) Thyroid hormones transcriptionally regulate the $\beta$ 1-adrenergic receptor gene in cultured ventricular myocytes. The Journal of Biological Chemistry 266(24): 15863-15869.

14. Babenko AY, Grineva EN, Savitskaja DA, Kravchuk EN, Solncev VN, et al. (2014) Polymorphisms of $\beta 1$-adrenoreceptor gene and cardiovascular complications in patients with thyrotoxicosis. Biomed Res Int T 2014: 402897. 
15. Kim M, Guzik TJ, Zhang YH, Zhang MH, Kattach H, et al. (2005) Myocardial Nox2 containing NAD(P)H oxidase contributes to oxidative stress in human atrial fibrillation. Circ Res 97(7): 629-636.

16. Popkova DA, Babenko AU (2010) Impact of endothelial nitric oxide synthase gene polymorphism $4 \mathrm{a} 4 \mathrm{~b}$ on the cardiovascular system in patients with clinical thyrotoxicosis of Graves' disease. Arterial Hypertension 16(2): 176-180.

17. De K, Ghosh G, Datta M, Konar A, Bandyopadhyay J, et al. (2004) Analysis of differentially expressed genes in hyperthyroid-induced hypertrophied heart by cDNA microarray. J Endocrinol 182(2): 303314.
18. Ozaydin M, Kutlucan A, Turker Y, Koroglu B, Arslan A, et al. Association of inflammation with atrial fibrillation in hyperthyroidism. J Geriatr Cardiol 9(4): 344-348.

19. Galloway A, Li H, Vanderlinde-Wood M, Khan M, Benbrook A, et al. (2015) Activating autoantibodies to the $\beta 1 / 2$-adrenergic and M2 muscarinic receptors associate with atrial tachyarrhythmias in patients with hyperthyroidism. Endocrine 49(2): 457-463.

20. Elnakish MT, Ahmed AA, Mohler PJ, Janssen PM (2015) Role of oxidative stress in thyroid hormone-induced cardiomyocyte hypertrophy and associated cardiac dysfunction: an undisclosed story. Oxid Med Cell Longev 2015: 854265.

\section{Your next submission with Juniper Publishers will reach you the below assets}

- Quality Editorial service

- Swift Peer Review

- Reprints availability

- E-prints Service

- Manuscript Podcast for convenient understanding

- Global attainment for your research

- Manuscript accessibility in different formats ( Pdf, E-pub, Full Text, Audio)

- Unceasing customer service

Track the below URL for one-step submission https://juniperpublishers.com/online-submission.php 